\title{
INTER BASIN WATER TRANSFERS IN INDIA - A SOLUTION TO HYDROLOGICAL EXTREMITIES
}

\author{
H. Mahabaleshwara ${ }^{1}$, H.M. Nagabhushan ${ }^{2}$ \\ ${ }^{1}$ Professor \& Former Principal, R.Y.M Engineering College, Bellary \\ ${ }^{2}$ Professor \& Dean, R.Y.M Engineering College, Bellary
}

\begin{abstract}
Water is treated as liquid gold since it is sacred and precious natural resource for health and wealth of the humanity. It is one and only the life sustaining elements of nature and second to "air" for survival of mankind and live stock on the earth. Earth is the only planet at present contains liquid water. The spatial and temporal uniformity in rainfall may possibly meet the water requirements for the various sectors such as Agriculture, Power, Industries, Domestic requirements etc., for the overall development of a region or country, If non uniformity is observed it results in the flooding situations in certain areas and drought conditions in some areas which have adverse impacts on the socio economic growth of a developing country. The government of India is spending enormous amount every year to overcome these natural unforeseen calamities. To protect a region or country from floods and droughts, it is inevitable to have a remedy/solution to transfer the water from surplus basin to deficit basins. The concept of Inter basin \& Intra basin water transfer can provide unique solution for the dual problems faced by the country like India.
\end{abstract}

India having geographical area of $328 \mathrm{MHa}$ stands as Seventh largest country in the world. The total water potential of India per annum is $4 \times 10^{6} \mathrm{Mm}^{3}\left(4000 \mathrm{~km}^{3}\right)$ including snow fall out of which $1.887 \times 10^{6} \mathrm{Mm}^{3}\left(1887 \mathrm{Km}^{3}\right)$ flows as river water. At present 1.033 $\times 10^{6} \mathrm{Mm}^{3}\left(1033 \mathrm{Km}^{3}\right)$ of water is utilized and balances as $0.854 \times 10^{6} \mathrm{Mm}^{3}\left(854 \mathrm{Km}^{3}\right)$ flows into sea and oceans. Also India experiences/ blessed with good rainfall in majority of the areas and scanty rainfall in few locations. The magnitude of average rainfall in North Eastern states of India is about $300 \mathrm{~cm}$ and less than $15 \mathrm{~cm}$ in North Western parts in the arid and semiarid regions. For the effective management of rain water in India the only alternative is to implementing Inter basin \& Intra basin concepts.

As per the studies conducted by NWDA(National Water Development Agency) about all river basis of India, it is remarked that Inter basin Water transfer is quite possible. NWDA proposed linking of Indian rivers under two components namely Himalayan and Peninsular components comprising perennial and non perennial rivers. Thus 30 links are proposed for benefiting water deficit basins from surplus basins, thereby flooding situations can be reduced and drought impact may be minimized to uplift for social and economical growth of India. The present paper throws a light on present rainfall and water potential scenario of India pertaining to interlinking of rivers which is on the top agenda of the country.

***

\section{INTRODUCTION}

The concept of the Inter basin water transfer is to be explored and implemented to ensure uniform distribution of available natural water resource and to mitigate the consequences of hydrologic extremes of floods and droughts. The implementation of Inter basin water transfer [1] is the need of the hour for the overall development of a country like India in which population is growing at an alarming rate. Also the Inter basin water transfer helps to prevent the formation of deltas along the coast line and migration of people from drought affected regions.

India has $1 / 6$ th of the global population and $1 / 25$ th of world's water resources, but the water availability is highly uncertain both in time and space due to its peculiar monsoonal climate. About $70 \%$ of the population directly or indirectly depends on agriculture, in the back drop of economic growth from industrialization. The urban population in the country is increasing at faster rate which requires the establishment of basic infrastructure, amenities and increase in food production. It is essential to convert rain fed crops into irrigation crops. At present the average food production is about $1.4 \mathrm{Ton} / \mathrm{Ha}$ which needs to be increased to 3.0 ton/Ha. Out of the net sown area of $140 \mathrm{M} \mathrm{Ha}$, the rain fed area is about $80 \mathrm{M} \mathrm{Ha}$ and remaining $60 \mathrm{M} \mathrm{Ha}$ is under irrigation. Nearly $78 \%$ of water harnessed is being used for irrigation and the balance $22 \%$ is used for domestic and Industrial requirements.

The basins of Ganga, Brahmaputra, Meghana and west flowing rivers constitute $27 \%$ of the drainage area and receive $72 \%$ of total rain fall of India. The important river basins of India are shown in Figure and the detail is presented.

The available storage in all reservoirs and tanks is only $55 \%$ of available surface water, considering 1.5 times filling. Hence it 
is required to utilize remaining $45 \%$ of surface water by creating the additional storage. The irrigation commission in 1972 has identified 67 drought prone districts comprising 326 taluks located in 8 states having an area of $49.73 \mathrm{M} \mathrm{Ha}$. Subsequently the national commission on agriculture in 1976 identified few more drought prone areas with slightly different criteria. The state wise drought affected areas are shown in the Table

The Criteria adopted to declare drought occurrence in an area are

1. When the annual rainfall is less than $75 \%$ of the normal in $20 \%$ of the years examined.

2. When less than $30 \%$ of the culturable area is irrigated.

The revised study made by Central Water Commission (CWC) in 2006 reveals that $51.12 \mathrm{M} \mathrm{Ha}$ area is drought affected in 74 districts. Thus in comparison to total geographical area of the country about $1 / 6$ th is drought prone area, Figure 1.2 shows location of drought prone areas of India.
Table 1: Drought affected States

\begin{tabular}{|l|l|l|l|l|}
\hline SNo & State & $\begin{array}{l}\text { Area } \\
(\mathrm{Ha})\end{array}$ & $\begin{array}{l}\text { Drought } \\
\text { area (Ha) }\end{array}$ & $\%$ \\
\hline 1 & Karnataka & 19177000 & 15240095 & 79 \\
\hline 2 & $\begin{array}{l}\text { Andhra } \\
\text { Pradesh }\end{array}$ & 27662000 & 12562382 & 45 \\
\hline 3 & Maharastra & 30776000 & 12418056 & 49 \\
\hline 4 & Tamil Nadu & 13007000 & 8327617 & 64 \\
\hline 5 & Rajasthan & 34222000 & 21408800 & 63 \\
\hline 6 & Gujarat & 19598000 & 12091618 & 62 \\
\hline 7 & Orissa & 15578000 & 2290000 & 15 \\
\hline
\end{tabular}

As per international standards per capita water requirement is $1700 \mathrm{~m} 3$ per year. If the availability is less than $1000 \mathrm{~m} 3$, it is considered as water scarcity. If it ranges between 1000-1700 $\mathrm{m} 3$ it is treated as water stressed. India with present availability of about $1600 \mathrm{~m} 3$ is under water stress condition. The North East river systems namely Ganga and Brahmaputra contribute $60 \%$ to nation's water resources where as 3 major southern river systems viz Godavari, Krishna and Cauvery contribute $6 \%, 4 \%$ and $1 \%$ respectively. The annual rainfall over the country is ranging from $10 \mathrm{~cm}$ in Rajasthan to 1100 $\mathrm{cm}$ at Chirapunji in Assam.

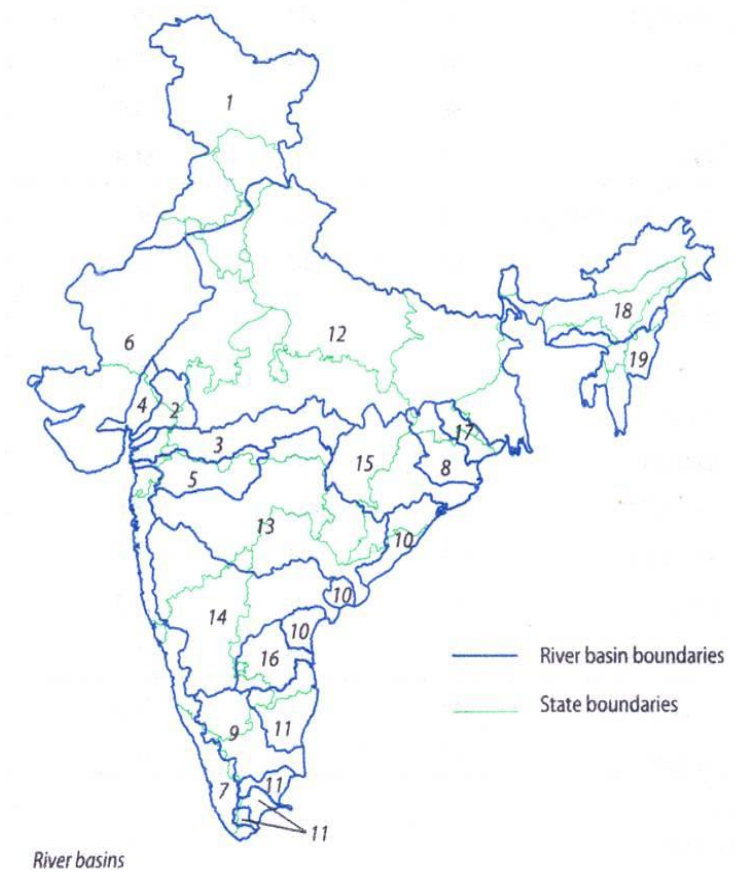

Fig -1: River basin map of India 
1. Indus

2. Mahi

3. Narmada

4. Sabarmati

5. Tapi
6. WFR1

7. WFR2

8. Brahmani \& Baitarani

9. Cauvery

10. EFR1
11. EFR2

12. Ganga

13. Godavari

14. Krishna

15. Mahanadi
16. Pennar

17. Subernareka

18. Brahmaputra

19. Meghana

Table 2: Water Resources Of Indian River Basins

\begin{tabular}{|c|c|c|c|c|c|c|c|}
\hline \multirow[b]{2}{*}{ SNo } & \multirow[b]{2}{*}{ Name of Basin } & \multirow[b]{2}{*}{$\begin{array}{l}\text { TRWR } \\
\text { Km3 }\end{array}$} & \multicolumn{3}{|l|}{$\begin{array}{l}\text { PUWR } \\
\text { Km3 }\end{array}$} & \multicolumn{2}{|c|}{$\begin{array}{l}\text { Water resources available per } \\
\text { capita m3 }\end{array}$} \\
\hline & & & $\begin{array}{l}\text { Surface } \\
\text { Water }\end{array}$ & $\begin{array}{l}\text { Ground } \\
\text { Water }\end{array}$ & Total & TRWR & PUWR \\
\hline 1 & Indus & 73.3 & 46 & 14.3 & 60.3 & 1501 & 1235 \\
\hline 2 & Mahi & 11 & 3.1 & 3.5 & 6.6 & 1649 & 990 \\
\hline 3 & Narmada & 45.6 & 34.5 & 9.4 & 43.9 & 2542 & 2448 \\
\hline 4 & Sabarmathi & 3.8 & 1.9 & 2.9 & 4.8 & 631 & 797 \\
\hline 5 & Tapi & 14.9 & 14.5 & 6.7 & 21.2 & 831 & 1183 \\
\hline 6 & WFR1 & 15.1 & 15 & 9.1 & 24.1 & 257 & 409 \\
\hline 7 & WFR2 & 200.9 & 36.2 & 15.6 & 51.8 & 3871 & 998 \\
\hline 8 & $\begin{array}{l}\text { Brahmani } \quad \& \\
\text { Baitarani }\end{array}$ & 28.5 & 18.3 & 3.4 & 21.7 & 1703 & 1296 \\
\hline 9 & Cauvery & 21.4 & 19 & 8.8 & 27.8 & 656 & 852 \\
\hline 10 & EFR1 & 22.5 & 13.1 & 12.8 & 25.9 & 1169 & 1346 \\
\hline 11 & EFR2 & 16.5 & 16.7 & 12.7 & 29.4 & 423 & 753 \\
\hline 12 & Ganga & 525 & 250 & 136.5 & 386.5 & 1418 & 1044 \\
\hline 13 & Godavari & 110.5 & 76.3 & 33.5 & 109.8 & 1441 & 1431 \\
\hline 14 & Krishna & 78.1 & 58 & 19.9 & 77.9 & 1133 & 1130 \\
\hline 15 & Mahanadi & 66.9 & 50 & 13.6 & 63.6 & 2463 & 2341 \\
\hline 16 & Pennar & 6.3 & 6.3 & 4.04 & 10.9 & 440 & 762 \\
\hline 17 & Subernarekha & 12.4 & 6.8 & 1.7 & 8.5 & 829 & 568 \\
\hline 18 & Brahmaputra & 585.6 & 24.3 & 25.7 & 48 & 17661 & 1448 \\
\hline 19 & Meghana & 48.4 & 1.7 & 8.5 & 10.2 & 4830 & 1018 \\
\hline
\end{tabular}

TRWRTotal Renewable Water Resources

PUWRPotentially Utilizable Water Resources

Table 3: Area Liable To Floods

\begin{tabular}{|l|l|l|l|l|l|}
\hline SNo & State & $\begin{array}{l}\text { Geographical } \\
\text { area (M Ha ) }\end{array}$ & $\begin{array}{l}\text { Area liable to } \\
\text { flood (M Ha) }\end{array}$ & $\%$ & $\begin{array}{l}\text { Area protected } \\
\text { ( M Ha ) }\end{array}$ \\
\hline 1 & Andhra Pradesh & 27.51 & 1.39 & 5.05 & 0.70 \\
\hline 2 & Assam & 7.84 & 3.15 & 40.18 & 1.305 \\
\hline 3 & Bihar & 17.39 & 4.26 & 24.50 & 1.566 \\
\hline 4 & Gujarat & 19.60 & 1.39 & 7.09 & 0.362 \\
\hline 5 & Haryana & 4.42 & 2.35 & 53.17 & 1.095 \\
\hline 6 & Himachal Pradesh & 5.57 & 0.23 & 4.13 & ----- \\
\hline 7 & Jammu and Kashmir & 22.22 & 0.08 & 0.36 & 0.012 \\
\hline 8 & Karnataka & 19.18 & 0.02 & 0.10 & 0.001 \\
\hline 9 & Kerala & 3.89 & 0.87 & 22.37 & 0.011 \\
\hline 10 & Madhya Pradesh & 44.34 & 0.26 & 0.59 & ---- \\
\hline 11 & Maharastra & 30.77 & 0.23 & 0.75 & 0.110 \\
\hline
\end{tabular}




\begin{tabular}{|l|l|l|l|l|l|}
\hline 12 & Manipur & 2.23 & 0.08 & 3.59 & 0.073 \\
\hline 13 & Meghalaya & 2.24 & 0.02 & 0.89 & 0.075 \\
\hline 14 & Orissa & 15.57 & 1.40 & 8.99 & 0.351 \\
\hline 15 & Punjab & 5.04 & 3.70 & 73.41 & 2.407 \\
\hline 16 & Rajasthan & 34.22 & 3.26 & 9.53 & 0.016 \\
\hline 17 & Tamil Nadu & 13.01 & 0.45 & 3.46 & 0.029 \\
\hline 18 & Tripura & 1.05 & 0.33 & 31.43 & 0.009 \\
\hline 19 & Utter Pradesh & 29.44 & 7.34 & 44.93 & 0.739 \\
\hline 20 & West Bengal & 8.88 & 2.65 & 29.84 & 1.001 \\
\hline 21 & Delhi & 0.15 & 0.05 & 33.33 & 0.023 \\
\hline 22 & Pondicherry & 0.05 & 0.01 & 20.00 & ---- \\
\hline & Total & & 33.52 & & 9.776 \\
\hline
\end{tabular}

\section{WATER CRISIS SCENARIO IN INDIA}

The estimated drought prone area is $51.12 \mathrm{M} \mathrm{Ha}$ and flood prone area is $33.52 \mathrm{M} \mathrm{Ha}$. By 2025 the estimated per capita availability of water may go down to $1340 \mathrm{~m} 3 /$ year, thus nearly $60 \%$ of Indian population will be living in water stress conditions. India produces about 200 Million Tons of food grains to feed the population of about 110 crores. In next 50 years the population is expected to grow to 160 crores, necessitating food production of 450 Million Tons. The country is to gear up to achieve it with proper perspective and vision. The culturable command area in the country is about $184 \mathrm{M} \mathrm{Ha}$ and the net sown area is about $140 \mathrm{M} \mathrm{Ha}$.

\section{NECESSITY OF THE STUDY}

As long as spatial and temporal uniformity in occurrence of rainfall is present, the water deficit and excess conditions do not arise. If not, the available water must be utilized properly by storage and transfer so as to satisfy the various needs uniformly over the entire country. In India the monsoons are highly orographic causing floods in North and North Eastern region and drought in other areas. The solution for storage and transfer lies in much talked about interlinking of rivers or inter basin water transfer.[11,12] As the Govt. of India is spending huge amount of money every year towards the relief of floods and drought, it is worthwhile to spend on inter basin and intra basin water transfer schemes keeping long term benefits in view. Moreover the inter basin water transfer is the only solution to maintain regional balance in all sectors like Agricultural, Industrial, Power generation, Domestic, Navigation etc.

\section{EXISTING INTER BASIN WATER TRANSFER PROJECTS IN INDIA AND OTHER COUNTRIES}

The concept of Inter basin water transfer is not new. In fact it was practiced in India and other countries long back and most of the projects of water transfer are still functioning well. Consequently many projects of large scale water transfer have been planned and some of them are implemented.
Examples of Inter basin water transfer in India

$>$ Periyar - Vaigai project (Kerala state 1985)

$>$ Kurnool - - Cuddapah Canal ( Andhra Pradesh 1863-1870)

$>$ Parambikulam - Aliyar project (1962-82)

$>$ Telugu - - Ganga project

$>$ Beas - - Sutlej Link (1983)

$>$ Indira Gandhi Nahar project ( Rajasthan canal, 1958)

$>$ Sarada - Sahayak Project (1960)

$>$ Ramganga - - Ganga Link (1978)

$>$ Tungabhadra - - Pennar project

$>$ Mahi project

$>$ Tehri Multipurpose project

\section{Other Countries}

CANADA: In Canada 16 inter basin water transfer schemes have been implemented for hydropower development.

USA: In United States, the California state water project, first phase of which was completed in 1973, provides for the diversion of $4 \mathrm{Km} 3$ of flow from surplus Northern California to the deficit central and southern parts of the state.

CHINA: In China there are schemes existing from ancient times which are recently supplemented by modern construction techniques. Now China is also planning for transfer of $48 \mathrm{BCM}$ of water from South to North through a Grand Canal close to Eastern coast. Recently completed projects in China include Biliuha-Dalian inter basin water supply system.

U.S.S.R: Among the Inter basin water transfer projects planned and implemented in USSR, the notable scheme executed in the central Kazakistana is Irtysh Karganda scheme

\section{NEW PROPOSALS FOR INTER BASIN WATER TRANSFER IN INDIA}

The concept of Interlinking of rivers was initially proposed by Sir Arthur Cotton in the year 1850 for Inland navigation purpose. Later in 1972 the then Central Irrigation Minister Dr 
K.L.Rao proposed Ganga-Cauvery link. In 1977 Captain Dastur proposed Garland of canal around the Himalayan, Central and Peninsular India. Later, Ministry of Water Resources and Central Water Commission formulated a National Perspective Plan (NPP) in 1980 to study water resources development in the country and transfer of water from surplus basin to deficit one [3] to minimize regional imbalance. NWDA (National Water Development Agency) was formed under NPP to further investigate and explore the possibilities of interlinking of rivers [6]. The broad objectives of NWDA [2] are

1. To promote systematic and scientific study of interlinking of rivers.

2. To carryout detailed study, survey, investigations of Peninsular and Himalayan rivers.

3. To identify possible water transfer projects/links to carry water from surplus basin to deficit one after meeting the existing and proposed needs.

4. To prepare feasibility reports of various components of Himalayan and Peninsular rivers.

After thorough investigations NWDA proposed to transfer 173 BCM of water through $12,500 \mathrm{Km}$ length of canal. As per NWDA, Inter basin water transfer is proposed in two components namely (1) Himalayan component and (2) Peninsular component. The proposed national water grid is given in Figure below. In this figure numbers 1-30 refer to the links considered under Himalayan (1-14) and Peninsular (1530) components as listed below.

\subsection{Himalayan Component}

This component mainly proposes to link Brahmaputra and its tributaries with the river Ganga and Ganga with Mahanadi. In addition it also proposes to transfer surplus flows of the Eastern tributaries of Ganga to the West. This component envisages construction of canal systems and storage reservoirs on the principal tributaries of Ganga and Brahmaputra rivers in India, Nepal and Bhutan. This component would provide additional irrigation to about $22 \mathrm{MHa}$ and power generation of about 30000 MW besides flood control in Brahmaputra and Ganga basins. The 14 links of Himalayan component are

Table 4: Himalayan Component

\begin{tabular}{|l|l|}
\hline 1 Brahmaputra-Ganga & 6 Yamuna-Rajastana \\
\hline 2 kosi-Ghagra & 7 Rajastana-Sabaramati \\
\hline 3 Gandak-Ganga & 8 Chemar- Sone barrage link \\
\hline 4 Ghagra- Yamuna & 9 Sone dam-southern Ganga \\
\hline 5 Sarada-Yamuna & $\begin{array}{l}10 \quad \text { Ganga -Damodar - } \\
\text { Subernarekha }\end{array}$ \\
\hline $\begin{array}{l}\text { 11Subernarekha- } \\
\text { Mahanadi }\end{array}$ & 13 Farakka-Sunderban \\
\hline 12 Kosi-Mechi & $\begin{array}{l}\text { 14 Brahmaputra-Ganga(Jogighopa- } \\
\text { Tista-Farakka) }\end{array}$ \\
\hline
\end{tabular}

\begin{tabular}{|c|c|}
\hline $\begin{array}{l}\text { 15.Mahanadi } \\
\text { (Manibhadra) } \\
\text { Godavari } \\
\quad \text { (Dowleswaram) Link }\end{array}$ & $\begin{array}{l}\text { 23.Cauvery (Kattalai) } \\
\text { Vaigai - Gundar Link }\end{array}$ \\
\hline $\begin{array}{l}\text { 16.Godavari } \\
\text { (Inchampalli) - Krishna } \\
\text { (Nagarjunasagar) Link }\end{array}$ & 24.Ken - Betwa Link \\
\hline $\begin{array}{l}\text { 17.Godavari } \\
\text { (Inchampalli Low Dam) } \\
-\quad \text { Krishna } \\
\text { (Nagarjunasagar } \quad \text { Tail } \\
\text { pond) Link }\end{array}$ & 25.Parbathi - kalisindh Link \\
\hline $\begin{array}{l}\text { 18.Godavari } \\
\text { (Polavaram) - Krishna } \\
\text { (Vijayawada Link) }\end{array}$ & 26.Par - Tapi - Narmada \\
\hline $\begin{array}{l}\text { 19.Krishna (Almatti) - } \\
\text { Pennar (Bukkapatnam) } \\
\text { Link }\end{array}$ & $\begin{array}{l}\text { 27.Damanganga } \quad-\quad \text { Pinjal } \\
\text { Link }\end{array}$ \\
\hline $\begin{array}{ll}20 . \text { Krishna } & \text { (Srisailam) }- \\
\text { Pennar } & \text { (Mylavaram } \\
\text { Link } & \\
\end{array}$ & 28.Bedti - Varda Link \\
\hline $\begin{array}{l}\text { 21.Krishna } \\
\text { (Nagarjunasagar) - } \\
\text { Pennar (Somasila)Link }\end{array}$ & $\begin{array}{l}\text { 29.Netravathi - Hemavathi } \\
\text { Link }\end{array}$ \\
\hline $\begin{array}{l}\text { 22.Pennar (Somasila) - } \\
\text { Cauvery (Grand Anicut) } \\
\text { Link }\end{array}$ & $\begin{array}{l}\text { 30.Pamba-Achankovil } \\
\text { Vaippar Link }\end{array}$ \\
\hline
\end{tabular}

\subsection{Peninsular Component}

In this component a network of interconnected river basins of Peninsular India is considered. NWDA carried out water balance studies of all the major river basins such as Mahanadi , Godavari , Krishna ,Pennar, Cauvery, Vaigai, West flowing rivers of Kerala, Karnataka, North of Bombay and South of Tapi and Southern tributaries of Yamuna to find out water surplus and deficit basins. The 16 links of Peninsular component are given below.

From Peninsular Component it is possible to irrigate about 13 M Ha and about 4000 MW of Hydropower can be generated. The Peninsular component utilizes 69.6 TMCum of water. This component involves the construction of storage reservoirs at potential sites in addition to the existing /ongoing reservoirs and a network of canals for water transfer. The following Table gives the details of proposed Interlinking of rivers 


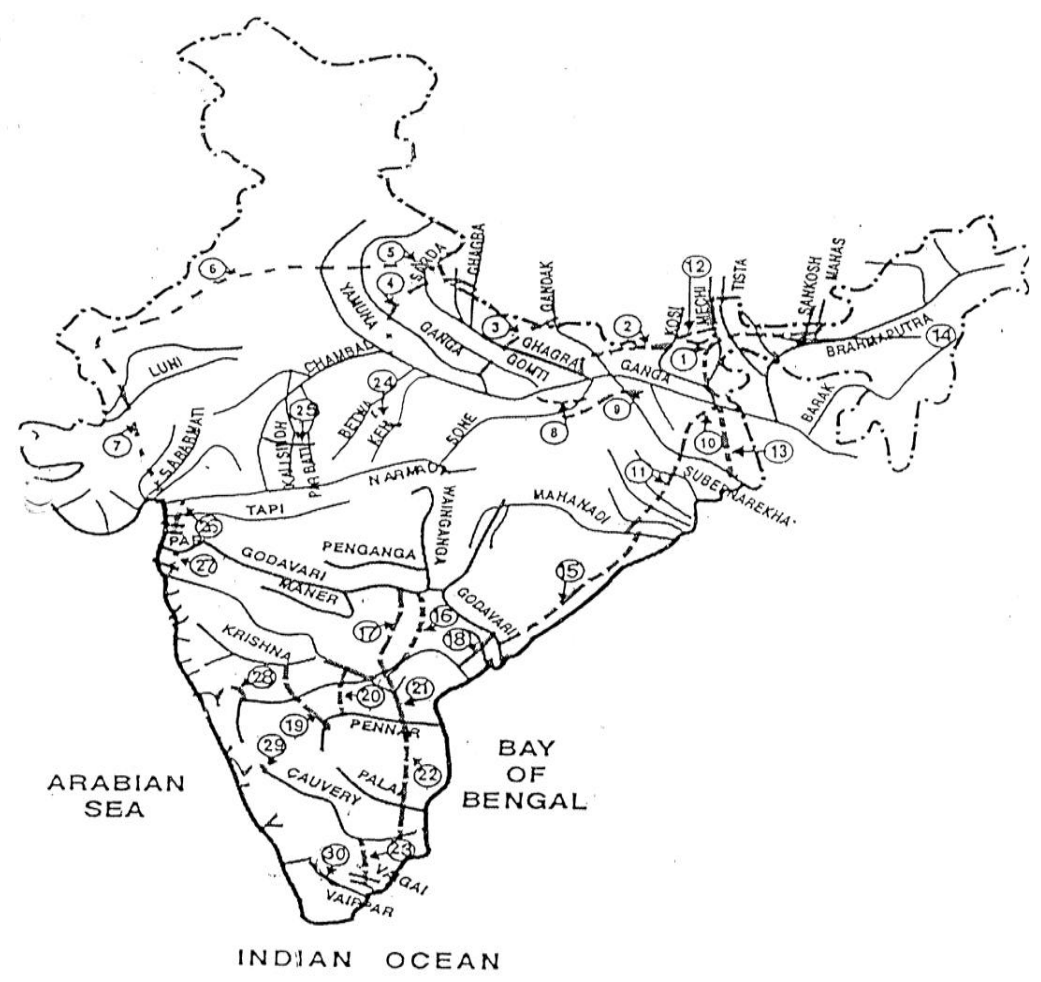

Fig.2: Proposed National Water Grid(NWDA)

Table 5: Details of Interlinking of Rivers

\begin{tabular}{|l|l|l|l|l|}
\hline S1. No & Particulars & $\begin{array}{l}\text { Himalayan } \\
\text { Component }\end{array}$ & $\begin{array}{l}\text { Peninsular } \\
\text { Component }\end{array}$ & Total \\
\hline 1 & Link Canal & 14 & 16 & 30 \\
\hline 2 & Major Reservoirs & 9 & 27 & 36 \\
\hline 3 & Total Length of Link Canals (Km) & 6100 & 4780 & 10880 \\
\hline 4 & Transferable Water (Km3) & 33 & 141 & 174 \\
\hline 5 & Power Generation (MW) & 30000 & 4000 & 34000 \\
\hline 6 & $\begin{array}{l}\text { Project Cost of Irrigation unit } \\
\text { ( Crores ) }\end{array}$ & 185000 & 106000 & 291000 \\
\hline 7 & Project cost of Hydropower Unit (Crores) & ------- & ------- & 269000 \\
\hline 8 & Additional Irrigation Area (MHa ) & 13 & 22 & 35 \\
\hline
\end{tabular}

Table 6: salient features of inter basin water transfers in india

\begin{tabular}{|l|lll|}
\hline 1. & Additional Irrigation & $:$ & $35 \mathrm{M} \mathrm{Ha}$ \\
\hline 2. & Hydropower generation & $:$ & 34000 to $40000 \mathrm{MW}$ \\
\hline 3. & The Cost of the project & $:$ & Rs 5,60,000 crores ( as per 2002 estimate) \\
\hline 4. & Water utilization & $:$ & $20.96 \mathrm{MHa}$ m \\
\hline 5. & Execution period & $:$ & 40 years \\
\hline 6. & Agricultural production & $:$ & 250 to 450 Million Tons \\
\hline
\end{tabular}




\begin{tabular}{|l|lll|}
\hline 7. & Total length of canals & $:$ & $10880 \mathrm{Km}$ \\
\hline 8. & Cost per Ha & $:$ & Rs 75000 \\
\hline 9. & Water availability & $:$ & $1122 \mathrm{~m} 3 /$ capita / year \\
\hline \multirow{3}{*}{10.} & Flood control & & \\
\cline { 2 - 4 } & Area can be protected & $:$ & About $40 \mathrm{M} \mathrm{Ha}$ \\
\cline { 2 - 4 } & Population protected & $:$ & About 260 Million \\
\cline { 2 - 4 } & Financial savings & $:$ & About 1200 crores per year \\
\hline \multirow{3}{*}{11.} & Drought protection & & \\
\cline { 2 - 4 } & Population benefited & $:$ & About 86 Million \\
\cline { 2 - 4 } & States benefited & $:$ & 14 \\
\cline { 2 - 4 } & Districts benefited & $:$ & 116 \\
\cline { 2 - 4 } & Financial benefit & $:$ & About 1200 crores per year \\
\hline 12. & Rivers involved & $:$ & 37 \\
\hline 13. & Reservoirs involved & $:$ & 60 \\
\hline
\end{tabular}

\section{MERITS AND DEMERITS OF INTER BASIN}

\section{WATER TRANSFER MERITS}

\subsection{Merits}

1. Possible to utilize the water resources uniformly and economically to yield Significant output.

2. Enhancement in Irrigation potential and power generation

3. Provides ample surface water to meet the growing needs of Domestic and Industries.

4. Scopes for Inland Navigation which reduces stress on existing communication system.

5. It minimizes the intensity of drought and floods.

6. It helps to increase per capita income.

7. Reduces the exploitation of ground water as surface water is made available in abundant.

8. Huge employment generation

9. Development of fisheries

10. Salinity control

11. Recreation facility

12. Infrastructural development

13. Socio economic development

14. Considerable improvement in ground water potential

15. Control in migration

16. Conversion of barren land into culturable land

17. Reduction in formation of further deltas in coastal zones.

18. Minimization of the relief expenditure towards floods and droughts.

\subsection{Demerits}

1. Large area liable for submersion due to construction of reservoirs and canals

2. Adverse effects over ecological system

3. Difficult to solve Interstate or International water disputes
4. Legal problem in sharing the water

5. Cost of the project and recurring expenditure for maintenance are high

6. Water pollution in conveyance

7. Loss of water in conveyance through the canals

8. Land acquisition and rehabilitation problems

9. Requires afforestation to compensate for loss in green

10. It is a long term project which may cause large variation in estimation

11. Serving for high altitude areas needs pumping of water which requires huge power and maintenance.

12. Needs huge debate at micro level and macro level on the issue to convince the public.

13. Problems of soil erosion and sedimentation

14. In undulated zones it may required to construct large number of cross drainage works.

\section{ESSENTIAL STUDIES AND ANALYSES}

To prepare a project report of water transfer scheme between two basins, the following studies and analyses are essential.

1. Water balance studies

2. Toposheet studies

3. Ecology and environmental impact assessment

4. Existing utilization and surplus of surface and sub surface water

5. Existing Irrigation, Industrial, domestic, power generation and other usages

6. Making International treaty and bilateral agreement between related states regarding water sharing.

7. Survey and Investigations

8. Water resources and hydrology

9. Preparations of plans, designs and estimates

10. Benefit cost ratio and financial returns.

11. Optimization studies for managing water resources 


\section{CONCLUSIONS}

The hydrological extremes of floods and droughts will have adverse effects on social and economical development of a country or region. The unique and long term solution for dual problem is inter basin water transfer. The study proves to be an authentic reference and resource for the planners, field engineers, administrators, researchers and the general public dealing with water resource exploitation, utilization and transfer. The following conclusions are drawn out of this work.

The next 50 years in India would witness a very large growth of urban centers. Many large urban centers would grow into metropolitan centers and meeting their water requirements would pose new challenges. The food production has to grow proportionally necessitating more allocation of water for irrigation. The inter basin water transfer proves to be the best option for the policy planners, administrators, professionals, media, NGO's and public to meet the challenges of the future. The entire surface water resource of the country is to be treated as national property so as to make its development and utilization uniform for the overall development of the country. Remote sensing and GIS tools can be utilized to carry out the hydrological, drainage, seepage and socio-economic analysis and the environmental impact assessment of the proposed water transfer projects. The basins of the water transfer scheme can be studied by developing digital elevation models (DEM) which help to generate the stream networks map, slope and aspect ratios of the basins.

\section{REFERENCES}

[1] Jonathan L Chenoweth, Hector M. Malano \& Juliet. F. Bird "Integrated River Basin management in the MultiJurisdictional River Basin: The Case of the Mekong River Basin” Journal of Water Resources Development vol 17, No 3, 2001, P 365-377

[2] NWDA (National Water Development Agency) India "A study on Inter- basin Water Transfer in India"

[3] Rajiv K Gupta "Human Rights Dimension of Regional Water Transfer: Experience of the Sardar Sarovar Project" Journal of Water Resources Development Vol 17, No 1, 2001, P 125-147

[4] Dr A.K.Chakraborty "Interlinking of Rivers - How can we use Space Technology to Resolve Survey \& Investigation Issues" National Seminar on Inter-Basin transfer of water in India - Prospects and Feasibility", P 10.1-10.5

[5] S.V.Chitale "Inter-basin Transfer by Water Grid Caution and Precaution"- The Indian Society for Hydraulics, Journal of Hydraulic Engineering , 2006, Vol 12(2), P 1-6

[6] Ramaswamy. R.Iyer "Linking of Rivers: Vision or mirage?" Published in India's National Magazine, The Publication of The Hindu - Vol 19 December 2002, Issue 25, P 1-7
[7] W.G.Yeh "Reservoir Management and Operational Models" A state - of - the Art Review, Water Resources Research, Vol 21, 1985, P 1797-1818

[8] Charles Revelle, Edward Joeres and William Kirby "The linear Decision rule in reservoir management and decision Development of the stochastic model" Water Resources Research, Vol 4,1969, P 767-777

[9] K.Can and Mark H.Houck "Real-Time Reservoir Operation by Goal Programming" Journal of Water Resource Planning and Management, ASCE Vol 110, 1984, P 297-309

[10] Slobodam,P.Simonovi "Reservoir System Analysis: Closing Gap between theory and Practice" Journal of Water Resources Planning and Management ASCE , Vol 118,1992, P 262-280

[11] H.Mahabaleswara \& G.Abbaiah "Inter-basin Water Transfers and Resolving Conflicts" International Conference on Hydrology and Watershed Management, 5-8 December 2006, Hyderabad

[12] H.Mahabaleswara, Dr.G.Abbaiah "Interlinking of Rivers" National Conference on Hydraulics and Water Resources with Special emphasis on Interlinking of Rivers, held at Bharathi Vidyapeetha Deemed University College of Engineering, Pune (Maharashtra -India ) 8-9 December 2006 